\title{
On The Waterfront: The Historic Waterfront Precinct, Dunedin, New Zealand
}

\author{
ALEXANDER TRAPEZNIK
}

sadly neglected area of New Zealand's built environment is its
industrial and mercantile heritage. Until recently, professional and
public interest has focused almost entirely on churches, grand and great houses, and public buildings. Unfortunately, industrial sites, where the majority of the population worked (or failed to work), have been given scant and perfunctory treatment by professional and government institutions vested with the responsibility of conserving the nation's heritage. Industrial and commercial heritage is very much a relevant category of social commemoration. Although utility is clearly a primary consideration, Peter Spearritt is correct when he asserts that money and taste rather than historical or cultural significance frequently determine which industrial sites survive. ${ }^{1}$ Like redundant churches, the fabric and the workings of industrial plants can often be read as a record of a particular phase in our history. ${ }^{2}$ To the workers 
who were employed in them they are a poignant reminder of their working conditions, industrial relations and technology in the same way as a church reminds its congregation of its spirituality and sense of community. In this way heritage can be defined in holistic terms and include the natural and cultural, the tangible and the intangible.

The context of this heritage can be revealed by adopting an historical landscapes approach. At an international level in the Nizhny Tagil Charter for the Industrial Heritage defines industrial heritage as something which

consists of the remains of industrial culture which are of historical, technological, social, architectural or scientific value. These remains consist of buildings and machinery, workshops, mills and factories, mines and sites for processing and refining, warehouses and stores, places where energy is generated, transmitted and used, transport and all its infrastructure, as well as places used for social activities related to industry such as housing, religious worship or education. ${ }^{3}$

Furthermore, the Charter states that industrial heritage

is the evidence of activities which had and continue to have profound historical consequences. The motives for protecting the industrial heritage are based on the universal value of this evidence, rather than on the singularity of unique sites... [Also] industrial heritage is of social value as part of the record of the lives of ordinary men and women, and as such it provides an important sense of identity. It is of technological and scientific value in the history of manufacturing, engineering, construction, and it may have considerable aesthetic value for the quality of its architecture, design or planning. These values are intrinsic to the site itself, its fabric, components, machinery and setting, in the industrial landscape, in written documentation, and also in the intangible records of industry contained in human memories and customs... [Finally] rarity, in terms of the survival of particular processes, site typologies or landscapes, adds particular value and should be carefully assessed. Early or pioneering examples are of especial value. ${ }^{4}$

New Zealand has inherited a significant legacy of structures resulting from colonial developments in areas such as agriculture, mining, shipping and railways, and processing industries. Their tangible remains can be found in cities, provincial towns and throughout the countryside. 
Only in recent times have there been endeavours to document and record this heritage. As Kathleen Stringer has noted, up until 'the 1980s, the industrial heritage of New Zealand was neglected by both the Historic Places Trust and historians in general. ${ }^{5}$ From the late 1960s onwards the focus has tended to be not on industrial heritage, but on the natural environment, on the conservation of rivers, parks, flora and fauna. 'Even now, the HPT register does not use the term "Industrial" but rather "Manufacturing and Processing"; this category has 107 listings. "Agriculture and Horticulture", on which foundations New Zealand was built, has 231 listings. In comparison, there are currently 514 religious buildings and a vast 1680 "residential buildings and associated places" listed. ${ }^{6}$ Also rather than having a myopic view of heritage we should take a historical landscapes approach, as the Nizhny Tagil Charter exhorts, and move away from single-site approach to a broad spatial context view of industrial heritage.

What makes a place historic should encompass the question of recording and interpreting history contextually. It is the construction of contexts which determines the process of historical interpretation when it is applied to traditional or archaeological sites, buildings and structures. The context may embrace a single event, or a series of events; it may represent the nucleus of a geographic place, or be associated with a noted individual or group.

A landscapes approach offers a holistic framework which recognises the inter-relationship of both the tangible and intangible elements of heritage. It provides relevance and context to the waterfront community and its visitors and enriches our understanding of the past - connecting it to the present and the future. This article will present a case study of the built heritage of a major nation-wide business, the National Mortgage Agency (NMA). This is one aspect of a larger project examining the historic waterfront area of Dunedin, New Zealand's first major commercial and industrial centre.

Nearly all landscapes have cultural associations because they have been affected in some way or another by human action or perception. The Dunedin waterfront commercial buildings can be further categorised as a particular type of cultural landscape: a historic local vernacular landscape, one which has evolved through use by people whose activities or occupancy have shaped that landscape. Through social or cultural attitudes of an individual, family or community, the landscape reflects the physical, biological and cultural character of those everyday lives. Function plays a significant role in vernacular 
landscapes. Examples include rural villages, industrial complexes and agricultural landscapes. ${ }^{7}$

A further explanatory framework which is important in interpreting cultural landscapes is a socio-spatial dialectical approach. In any society there is not a single context but a series of contexts at a variety of spatial scales which allow different individuals and groups, depending upon how much access to power and other resources they have, differentially to arrange and modify these different contexts. The poor and less affluent have an impact upon the immediate context of their neighbourhoods while the rich and powerful may leave their mark at the national, or even international, level. Regardless of the power of different cultural groups, they all create cultural landscapes to varying degrees and interpret them from their own perspectives. This gives rise to tensions and contradictions.

A socio-spatial dialectical approach is useful to understanding cultural landscapes. Whilst a term such as 'historical' suggests a link to human actions, individual and collective, the term 'spatial' or 'landscape' typically evokes the image of something physical and external to a social context. Traditionally, space is a context for society, a container, rather than a structure created by society. Nevertheless, human ideas are expressed in behaviour which then creates cultural landscapes. These landscapes, in turn, affect behaviour and ideas in endless causal loops: cultural landscapes dialectically show cause and effect. Social and spatial relationships are dialectically inter-reactive and interdependent. Cultural landscapes reflect social relations and institutions, and they shape subsequent social relations. While elites create spatial inequalities and homogeneity simultaneously through their hegemony, non-elites create counter-hegemonic landscapes which reflect their own values. Behavioural resistance to the dominant culture leads to distinctive cultural landscapes: for example, in the New Zealand context, cultural resistance by the Maori.

In the New Zealand context there is a paucity of sources on industrial heritage. Geoffrey Thornton's New Zealand's Industrial Heritage provided the first survey of industrial archaeology in the country. It is an ambitious undertaking in which he attempts to trace the history of industry in nineteenth-century New Zealand, but unfortunately does not address any theoretical debate about industrial archaeology and focuses only on buildings. Nigel Smith, nearly 20 years after Thornton's book, attempted a similar overview of New Zealand's industry and it too lacks a certain cogency and coherence in its approach to the topic. ${ }^{8}$

Historians and historical geographers are showing increasing interest in urban heritage. One influential work is Brian Graham, G. J. 
Ashworth and J. E. Tunbridge's A Geography of Heritage: Power, Culture and Economy. ${ }^{9}$ It analyses the social and political uses of heritage in the cultural sphere, including its relation to national identity and the questions of what is considered 'heritage' and to whom it is believed to belong. They also consider the economic role of the 'heritage industry'. Of particular interest here is the authors' analysis of European urban waterfront heritage developments, in particular their preservation and adaptive re-use.

Many industrial or former industrial cities see the preservation and development of precincts of historic buildings as a route to economic rejuvenation through tourism. Bella Dicks, in her Heritage, Place and Community, has made a case study of the Rhondda Heritage Park in South Wales and its attempt to revive the local economy and the cultural identity of the community. ${ }^{10}$ In New Zealand, a comparable approach has been taken in the recently revived Whitestone heritage precinct in Oamaru, North Otago.

Heritage as an economic resource tends to focus on the distinctive and exceptional. But as David Atkinson points out in his 'The Heritage of Mundane Places', heritage can be more open and accessible: 'something that can be explored through a series of more everyday, mundane places. ${ }^{\prime 11}$ The Spotswood Industrial Heritage Precinct at Hobsons Bay near Melbourne is analogous to Dunedin's historic waterfront area. It is a large industrial precinct including structures built for a range of processing, manufacturing, transport and refining industries from the 1840 s to the mid-twentieth century. ${ }^{12}$

The study of the relationship between heritage and history has been strongly influenced by David Lowenthal's publications. In Possessed by the Past he defines the relationship between history and the 'cult of heritage' as one where the former explains the past while the latter infuses the past with present purposes. ${ }^{13}$ This work developed the ideas set out in The Past is a Foreign Country, which traced changing perceptions of the past over the last two centuries. ${ }^{14}$ More recently, David Harvey has discussed the development of theoretical work on heritage and provided a case study of changing attitudes over the past three centuries towards a prehistoric site. ${ }^{15}$ For New Zealand, the development of concern for the historic urban built environment was traced by P. J. Perry and K. Galletly in 'The Preservation of Historic Buildings in Urban New Zealand: Precedent, Practice and Policy'. ${ }^{16}$ Consideration of Dunedin's historic waterfront precinct expands on this while also contributing to comparative studies of the heritage of other settler societies such as Canada and Southern Africa, which are 
discussed by J. E. Tunbridge and G. J. Ashworth in their Dissonant Heritage: the management of the past as a resource in conflict. ${ }^{17}$

A recent critique of the 'authorised heritage discourse' that has developed, and which is particularly relevant to this study, is provided by Laurajane Smith in Uses of Heritage. ${ }^{18}$ She argues that the definition of what constitutes heritage is determined by power relations, and is inherently political. Heritage is therefore best understood as a dynamic cultural process by which people use the past, rather than simply in terms of buildings or objects; that is, heritage is a 'discursive construction' with material consequences for how people relate to historic sites or events. In Dunedin, this process is exemplified by the waterfront precinct of commercial and industrial buildings constructed in the last third of the nineteenth century on newly reclaimed harbourside land in the city centre.

\section{DUNEDIN'S WATERFRONT BUILDINGS}

This article draws on research for a much larger project covering more than 60 'old waterfront' buildings, most of which were built in the late nineteenth century during Dunedin's industrial golden age, when it was the largest and most industrialised city in colonial New Zealand. ${ }^{19}$ These extant buildings would, could we unlock their histories, tell of a time when Dunedin epitomised how feasible it was to achieve relative wealth in a new country thousands of miles away from overcrowded Great Britain. This fast-changing and rapidly growing settlement was very different to the city we know now. The surviving buildings are a link to the power relations of the past and provide an especially good example of heritage as a dynamic cultural process.

Most of the boom-time development of the 1860s, 1870s and 1880s occurred in a nucleus around lower Rattray and Jetty Streets - the latter originally so named because the main jetty for shipping was at the end of it. Early photographs show a conglomeration of industrial settlement at the water's edge. As a result of successive reclamations during the second half of the nineteenth century, this development gradually crept seaward as more and more urban turf was poured onto the seabed of the harbour. The land reclaimed in the 1870s was expected to provide 'the most valuable building sites for the metropolis of the future. ${ }^{20}$ Beginning with Bond Street in 1864, by 1875 reclamation had reached as far as the east side of Crawford Street. By 1898, dry land went all the way to Cumberland Street, then over a new railway line to the streets around what became known as the Steamer Basin. ${ }^{21}$ This reclamation created new land on which to build warehouses, offices and foundries. ${ }^{22} \mathrm{In}$ 
addition to the reclamations, new buildings were erected in stone or brick in established areas following the various fires that ravaged the closely packed wooden buildings in the $1860 \mathrm{~s} .{ }^{23} \mathrm{~A}$. H. McLintock summed up the 'progress' thus:

at Dunedin, where former swamps and tidal flats threw wide a challenge to man's enterprise, the facts themselves speak eloquently. For a city has emerged from harbour spoil, and streets and factories and wharves have taken shape as the waters have receded. ${ }^{24}$

This area, which for the purposes of this study will be known as the historic waterfront area, is today the southern end of the built-up part of the city, where the 'one-way' road systems run north and south. Here the average Dunedin shopper can find a range of homeware stores, along Crawford Street in particular. But everywhere around this old waterfront area, the ghostly and often decrepit monuments to Dunedin's former glory remain - numerous Victorian buildings and other old warehouses in various states of disrepair. What business did they do? What place in our society did they once have, and still have?

Dunedin was founded in 1848 on a site that had no earlier permanent settlement. It was a struggling township until it was transformed by the discovery of gold further inland in 1861. It became a 'small and relatively cohesive community, dominated politically and morally by [Scottish] Free Church [Presbyterian] proponents of organized settlement, fast became a large and sprawling population, indifferent or even hostile to the pretensions of the founders.' Its province, Otago, became the richest and most populous in the country: $£ 21$ million worth of gold was extracted within a decade, after which bullion exports slumped to a level they would remain at for the rest of the century. By 1870, Otago contained a quarter of the non-Maori population of the entire country and a produced a third of its exports, much higher proportions than became the case in the later twentieth century. The demand created by the gold rush made many farmers, merchants and professional men prosperous. A powerful business elite formed that was 'increasingly held together by complex family, business, and social links'. Many new businesses were established, attracting investment from Victoria and Scotland in particular. Otago had been one of the least industrialised parts of the country, but rapidly caught up with and surpassed other provinces. As Olssen has noted, 'Dunedin became the major entrepôt... for much of New Zealand. ${ }^{25}$ 
Many of the buildings in the historic waterfront area were, in different ways, related to New Zealand's early development in cropping and farming. In particular, they relate to the stock and station industry which provided farmers with the expertise to sell their goods, store them and transport them. Their offices and warehouses formed the port-side infrastructure for the storage, sale and shipping of our earliest export offerings. The idea, still often expressed today, that the rural areas underpinned the economic strength of New Zealand towns, could not have been more accurate for Dunedin's early development. Yet it is a factor in the development of Dunedin, and of New Zealand more generally, that is often overlooked. It is difficult, in a milieu of what often seem to be clichés about New Zealand's history, to see the tangible early evidence for this so-called vital town/ country inter-dependency. Yet the evidence, in the form of these buildings, exists in Dunedin - but only just. Although joint-stock companies began appearing, wealth was still largely personalised and 'family capitalism' (characterised by individual or family firms) was the norm. The meat and shipping industries were the most corporatized activities, and provide exceptions to the 'family capitalism' model.

The NMA's surviving buildings provide a good illustration of this urban-rural interdependency and Laurajane Smith's concept of heritage being a 'discursive construction'. Embedded within the histories of these buildings - who used them, and how - is not just a local, but a national history of how colonial New Zealand found its industrial and commercial feet. Dunedin was at this time at the cutting edge of industrial growth in New Zealand, and the most industrialised city ahead of Christchurch, Wellington and Auckland. This makes the surviving buildings important to our national heritage; our sense of where we came from and how we worked when we got here. Oamaru has its harbour-side heritage precinct, but the irony is that Dunedin, where the head offices and largest warehouses were, and in many cases still are, is yet to achieve any similar recognition. These buildings are for the most part commercially neglected today.

\section{HISTORICAL BACKGROUND: THE 1870S AND 1880S}

Dunedin was at its industrial nadir in the 1870s. It 'was still, but only just, the most industrialised city in New Zealand... [i]n 1873 solid stores and warehouses were being built on newly reclaimed ground... by 1874 , the prosperity initiated by the gold rushes was being stimulated and maintained by the Vogel public works and immigration policy. Between 
1872 and 1875, almost 18,000 people arrived in Otago - a larger number to arrive than at any other province. ${ }^{26}$

Many of the businesses established in the 1860s grew rapidly and expanded into other regions, some surviving well into the twentieth century. Yet the development of New Zealand's agricultural industry was already underway before the gold rush began. The wool industry provided the bulk of export receipts as early as 1857 along with the trade in wheat, potatoes and oats. ${ }^{27}$ Yet the biggest growth in non-gold trade occurred in the 1870s and early 1880s. Dunedin was the commercial capital of the country, 'a busy, confident place, only gradually modified by the long depression of the eighties and nineties'. Many major businesses were established in the 1870s, several of which have survived to the present day. ${ }^{28}$

William N. Blair gave a snapshot of this industrial era when most of the buildings researched for this project were built. He came to Dunedin in 1863 to work as a civil engineer for the Otago Provincial Council Otago's first major governing body - and later became assistant engineer-in-chief of the New Zealand government's Public Works Department. ${ }^{29}$ Blair noted in 1887 that 'without agriculture, the establishment of manufactures would be impossible. Thus the various branches of settlement and trade create and produce others; they act and react on each other, nourishing and fostering each his neighbour in the general march of progress. ${ }^{30}$ He noted that by 1887, Otago and Canterbury exported two thirds of the nation's wool, and the Southern provinces had developed a clothing and woollen industry of which they could be proud: 'We make cloth and clothes with the cloth... the New Zealand clothing mills produce a great variety of fabrics suitable for all purposes of humanity, old and young, savage and civilised.' He also observed that the grain market by 1887 had 'collapsed', having been 'swamped in the London market by the cheaper production of America and India.' The frozen meat trade, however, was on the rise. Other industries prospering in the South included agricultural implement manufacturing, brick and tile works, quarries, steel works, brewery plants, export manure, rope, candles, soap and earthenware manufacture. $^{31}$

William Blair's descriptions are a crucial resource for this study, because without a doubt the major theme of the uses of these buildings is agriculture and processing - in fact the words 'wool' and 'grain' stores can still be seen on the old NMA Store in Vogel Street, and possibly can be made out also on the Donald Reid and NZLMA stores. These two commodities, first grain, and then wool, were the new gold in terms of 
exports by the 1870s. Correspondingly at this time the stock and station industry was in an expansionary phase. The other industries Blair mentions were literally spun off the sheep's back, showing how very quickly New Zealand became entrepreneurial, and self-sufficient in making its own clothes and other household commodities - a very different picture to the import-dependence the developed from the 1980s. At the start of our industrial history, New Zealand was expected not to compete with Britain, but very quickly people like Blair felt there was no reason why New Zealand could not create its own industries and cater to its own needs. ${ }^{32}$ This theme also comes through when one delves into the individual histories of these firms: their owners were New Zealand's industrial pioneers with humble immigrant beginnings, but who later acted on opportunities they found here and collectively helped to form New Zealand's industrial backbone.

Industry grew in a process of interaction - they acted and reacted on each other. As Blair put it, 'thus the various branches of settlement and trade create and produce others.' Jim McAloon reinforces the point that there was much interlocking of businesses in Otago, with many directors sitting on more than one board, and many companies having rich directors. ${ }^{33}$ This is startlingly obvious in how the NMA operated. Its manager, John Macfarlane Ritchie, had board connections to the pioneering Union Steam Ship Co, National Insurance and the New Zealand and Australian Land Co. In the age before telecommunications, all he had to do was walk out of his office in Bond Street, and down to the corner of Water and Vogel Streets, a stone's throw away, to do business. There is a good reason why so many businesses, essentially performing different functions within the same trade, were located cheek by jowl in this way: there was no other way of discussing ideas and concepts freely except through face to face contact. In this way, through this process of 'nourishing and fostering' each other, financial empires were built, worth a lot of money in their day. As Jim McAloon concludes, we may in general speak not of 'a single and extensive intercorporate system', but rather of a relatively small-scale interpersonal system. ${ }^{34}$

\section{THE NATIONAL MORTGAGE AGENCY AND ITS BUILDINGS}

The National Mortgage Agency (NMA) provides a good example of the large enterprises based in this physically compact area which survived into recent times and which has left an extensive physical legacy in the historic waterfront precinct. It was one of the pioneering stock and station agents in New Zealand, associated with the establishment of 
viable farms and instrumental in many of the earliest selling and shipping innovations. Simon Ville concludes that there is 'no doubt that over the last 150 years, stock and station agents have played a central and guiding role in the success of the farming sector in Australia and New Zealand. ${ }^{35}$

The NMA was to become a major player in the New Zealand stock and station scene for the next century, vestiges of which survived into 1970s and 1980s as Wrightson NMA. This national firm is now part of agriculture-based firm PGG Wrightson (which also took over Reid Farmers). The NMA started with branches in Otago, Southland, Canterbury and Melbourne. It also had North Island interests, including meat processing 'freezing works'. Fortunately for the purposes of this study, all their Dunedin buildings survive. However, its grandest legacy, the former Union Steamship Company head office, is in a very poor state of repair.

The NMA was formed in 1878 when a London-based company bought two South Island stock and station firms. ${ }^{36}$ As well as wool, the firm also advanced money on land for settler farmers in Otago, Southland and Canterbury. The affairs of the company were conducted from its head office in Lombard Street in London and board meetings were held there. ${ }^{37}$ The NMA was a 'foundation member' of the refrigerated meat export business. ${ }^{38}$ The firm's activities developed as the rural economy changed in the 1890s:

From the 1890s NMA emphasised stock and station agency business rather than mortgage finance. The company concentrated on selling produce on behalf of farmers, supplying them with inputs, and conducting livestock auctions, and it financed farmers primarily by current accounts and to a lesser extent by advances on produce... The changing rural economy reinforced the transformation. The introduction of refrigerated shipping in 1882 had been a necessary but not sufficient condition for the creation of a prosperous smallfarming sector. From 1891 the Liberal government actively promoted closer settlement. At the same time,... many estateowners began to subdivide on their own account, especially as commodity prices rose after 1896 . Once the land market began to move again, doubtful assets and accounts could be dealt with, and large runholders' accounts reduced to a satisfactory level. Of the greatest long-term importance, closer settlement meant that financiers' risks were much more widely spread, with many more farmers each borrowing much less. ${ }^{39}$ 
The NMA's business was 'the lending of money on the mortgage of freehold and other securities; consignments of produce, such as grain, wool, tallow, frozen meat, sheep and rabbit skins, hemp, butter and cheese. ${ }^{40}$ All these goods were 'accepted by the company at any of its branches, and liberal advances are made to consigners pending realisation. The company conducts business as auctioneers, and acts as stock and station agents, shipping and general commission agents; and regular and periodical auction sales are held - under the company's auspices - by its auctioneers.' The firm also acted as shipping agents. ${ }^{41}$ In 1970, the head office moved to the capital, Wellington, 'seeking closer proximity to financial, commercial and Government contacts'. ${ }^{42}$

Ville shows how the way the NMA operated highlights how the Dunedin business community networked to create business and increase New Zealand's wealth out of the rural sector:

N.M.A. did [its] banking with the National Bank of New Zealand, much of its shipping was with the U.S.S. Co; its Insurance was with National Insurance and it acquired its agricultural equipment from Reid and Gray Ltd (also a Dunedin agricultural implement manufacturing firm in Princes and Crawford Streets). Personal business links drew these firms together. ${ }^{43}$

Ville further notes the closeness of these major firms where, in the early twentieth century, J. F. Ritchie's son G. F. Ritchie was chairman of the USS Co and National Insurance, and also sat on the boards of other 'closely linked companies.' Conversely James Mills, the chairman of USS Co for many years, also sat on the board of the NMA: 'These firms had contiguous head offices in Water Street... and indeed exchanged premises on several occasions... In the development of the frozen meat shipments from Dunedin to London starting (in Dunedin) in 1882, a key figure was William Soltau Davidson, whose links with NMA's circle were critical in bringing together the various parties for the project. ${ }^{\prime 4}$

\section{NMA BUILDINGS AND OFFICES}

There were three headquarters, all still standing, in the Water Street area, a precinct in the historic waterfront area. The first and oldest, 24 Water Street, ${ }^{45}$ was built 1877 and appears to be well maintained and tenanted. This stone, plaster and brick building is located on the corner of Water and Bond Streets, opposite the back of John Wickliffe House. In the early days, it probably also acted as the warehouse for the firm. 
The second head office, 38 Water Street ${ }^{46}$ is one block back towards the railway line, on the corner of Vogel and Water Streets (west side). This plaster-rendered brick building - not as ornate as its predecessor was their headquarters from 1905. It appears to be empty now, but still seems to be in relatively good condition. It bears the words Union Steamship Company engraved in plaster along the top - as it became the USS Co's headquarters in 1929 in what was effectively a swap of headquarters with the NMA.

The most recent NMA headquarters, 49 Water Street, ${ }^{47}$ with frontages to Cumberland, Water and Vogel Streets, was built as the USS Co's head office some time before $1890 .{ }^{48}$ It was designed by David Ross, 'undoubtedly one of the most important architects who have worked in Dunedin'. ${ }^{49}$ The NMA took it over in 1929 and moved out in the 1970s. It is ominously called a 'sadly defaced hulk' in the Dunedin City Council's Draft thematic study of June 2009 by Michael Findlay and Salmond Reed Architects. ${ }^{50}$ A grant of $\$ 20,000$ was made by the City Council in 2010 towards restoration work, which is now under way. ${ }^{51}$

The building was given a 'facelift' after 1929 when the vestiges of Victoriana, most of its Italianate architectural ornamentation, were removed from the outside walls. It appears at that time to have been plastered over and made plain, with incised decoration more in a minimalist art deco style. It still carries the name 'National Mortgage \& Agency Coy of NZ Ltd' emblazoned on its peeling walls and 'NMA' cast into the grilles covering the sub-basement windows.

The site chosen had prospects for the future, as the local morning newspaper the Otago Daily Times commented in 1883:

[the site] is eminently an advantageous one, although it is not at present actually in the commercial centre of the city. Nevertheless, by the time the new railway station is opened, and when the newly-made streets shall have become thoroughly populated, the wisdom which has dictated the choice will be pretty generally recognised..$^{52}$

\section{The UNION SteAmShip Company of NeW ZeaLAND}

The company that built this originally grand headquarters was started in 1875 by prominent early businessman and landowner Johnny Jones' former business partner in shipping James Mills (1847-1936)..$^{53}$ After consolidating the Port Chalmers-Dunedin trade, Mills worked on establishing links with all other southern ports and obtained a subsidy from the provincial government to do so. According to Erik Olssen, 'Dunedin thus became the southern entrepôt. ${ }^{54}$ Mills then sought to 
secure control over the inter-provincial trade and by 1874 was 'the uncrowned King of the Dunedin waterfront'. ${ }^{55}$ 'Within three years', quoting Olssen again, 'the new company had achieved dominance in the coastal trade and the inter-colonial trade, over the next decade freight rates fell by half, and Mills had become the leading entrepreneur in Otago and one of its wealthiest citizens. ${ }^{56}$ By 1880, Mills had helped ensure 'the U.S.S. was the largest shipping company in the Southern Hemisphere, and before 1940 the largest employer of labour in New Zealand outside the Government. ${ }^{57}$

The USS, or red-funnel fleet as it became known, became a major player in the decade 1875-85, becoming the 'premier shipping line in the Southern Hemisphere and in doing so carried the name Dunedin into just about every port of consequence in Australasia.' Its grand head office on reclaimed land on the corner of Water and Vogel Streets 'symbolised Dunedin's maritime aspirations' ${ }^{58}$ and was on the waterfront when first built.

\section{THE NMA'S WAREHOUSES}

Three NMA warehouses also survive: the first is a large four-storey brick and plaster building in Cumberland Street next door to the company's last Water Street headquarters - with a frontage also to Vogel Street. It was given a 1920s facelift in the same art deco style as the head office. Its date of construction is not known, but it appears from its early photographs to be before 1900. The second is the NMA Wool and Grain store, a large, long and prominent two-storey brick building taking up one side of an entire block. It is unclear when this building was constructed, but in the 1888 and 1892 City of Dunedin block plans it shows up as the Farmer's Agency wool and grain store, which the NMA later took over. This building is now partially occupied by a Beaurepaires tyre store.

The third surviving NMA warehouse is now the Spotlight store - in plaster-rendered brick with a saw-tooth roof - was the NMA's most recent Dunedin store. This building was constructed in the early part of the twentieth century, and was later known as the orange Hirequip building before becoming the Spotlight retail store. It shows up on the 1927 Fire Plan map as a wool and manure store, but not on the earlier 1892 Fire Plan as an NMA building. In the 1888-89 City of Dunedin block plan, the same site is marked as being owned by Milburn Lime and Cement works. John McFarlane Ritchie of the NMA was a director in the cement works company in 1903. Its head office was listed as Cumberland 
Street, Dunedin - perhaps the same site or building Ritchie later acquired for the NMA. ${ }^{59}$

\section{CONCLUSION}

This precinct of inter-related commercial and industrial premises, aside from its inherent architectural interest, is significant for what it shows about the interconnectedness of commercial enterprises for at least a century from the 1870s, and how they developed over time. It serves as a physical reminder that nineteenth-century Dunedin was not merely a boom town based on the profits of gold mining but from the 1860s and 1870s established an enduring manufacturing and financial base. Stock and station agents, not least the NMA, played a central role in linking the urban and rural economies and connecting New Zealand with wider imperial and world trading networks. Locally, the close connections between manufacturing, finance and shipping are still evident in the physical layout of the historic waterfront precinct.

The precinct is a clear example of an historic cultural landscape that has evolved over time and continues to reflect the activities and occupancy of those people who have shaped the landscape. It reinforces Laurajane Smith's argument that heritage is a dynamic cultural process, one that is inherently political as it is determined by power relations. The Dunedin waterfront precinct is a cultural landscape that on closer examination clearly reflects social relations and institutions, and has helped shape social relations over the past century and a half. The importance of face-to-face contact in the commercial world, not merely in the nineteenth century but well into the twentieth, is conveyed clearly by the relatively intimate compactness of the precinct.

When the NMA relocated, each time it moved only a little further down the street. The awareness of the physical dimension to business history forms an important part of the holistic framework provided by a landscapes approach to the historic waterfront precinct, and helps shift the focus away from the traditional emphasis on churches, great houses and public buildings and onto the comparatively mundane places. As the Nizhny Tagil Charter says, such early examples of surviving heritage landscape as the Dunedin waterfront precinct 'are of especial value'. ${ }^{60} \mathrm{~A}$ cultural landscapes approach therefore is a particularly valuable one, as it provides a holistic view of heritage, both tangible and intangible.

\section{ACKNOWLEDGEMENTS}

This article is based in part on research conducted by Joanne Galer and was revised by Austin Gee. 


\section{ENDNOTES}

${ }^{1}$ P. Spearritt, 'Money, Taste and Industrial Heritage', in J. Rickard and P. Spearritt (eds), Packaging the Past? Public Histories, Melbourne University Press, Melbourne, 1991, p33.

2 ibid, p39.

${ }^{3}$ The Nizhny Tagil Charter for the [sic] Industrial Heritage, July 2003.

${ }^{4}$ ibid.

${ }^{5}$ Kathleen Stringer, 'Investment, Innovation, Involvement: Clarks' Flour Mill, Maheno, North Otago', PGDip (Arts) dissertation, University of Otago, Dunedin, 2009, p10.

${ }^{6}$ ibid.

${ }^{7}$ Charles A. Birnbaum, Protecting Cultural Landscapes: Planning, Treatment and Management of Historic Landscapes, Preservation Brief, 36, US National Park Service, Washington, DC, 1994, p1.

${ }^{8}$ Geoffrey G. Thornton, New Zealand's Industrial Heritage, A. H. and A. W. Reed, Wellington, 1982; Nigel Smith, Heritage of Industry: Discovering New Zealand's Industrial History, Reed Books, Auckland, 2001

${ }^{9}$ Brian Graham, G. J. Ashworth and J. E. Tunbridge, A Geography of Heritage: Power, Culture and Economy, Arnold, London, 2000.

${ }^{10}$ Bella Dicks, Heritage, Place and Community, University of Wales Press, Cardiff, 2000. Proposals for similar industrial heritage tourism centred on the Jeep factory complex in Toledo, Ohio, have come to nothing, however, with the demolition of almost all the original buildings. Philip Feifan Xie, 'Developing industrial heritage tourism: A case study of the proposed jeep museum in Toledo, Ohio', Tourism Management, vol 27, 2006, pp1321-30.

${ }^{11}$ David Atkinson, 'The Heritage of Mundane Places', in Brian Graham and Peter Howard (eds), The Ashgate Research Companion to Heritage and Identity, Ashgate, Aldershot, 2008, p386. The chapter, pp381-95, provides examples from waterfront heritage areas of Bristol and Hull. ${ }^{12}$ It is described in the Hobsons Bay Heritage Study: City of Williamstown Conservation Study Review, vol 1b: Thematic Environmental History, Hobsons Bay City Council, Hobsons Bay, 2003. This is available online at: http:/ / www.hobsons.vic.gov.au/

${ }^{13}$ David Lowenthal, Possessed by the Past: The Heritage Crusade and the Spoils of History, Free Press, New York, 1996, pxi.

${ }^{14}$ David Lowenthal, The Past is a Foreign Country, Cambridge University Press, Cambridge, 1985.

${ }^{15}$ The neolithic stone circle at Avebury, Wiltshire: David C. Harvey, 'The History of Heritage', in Graham and Howard (eds), The Ashgate Research Companion to Heritage and Identity, pp19-36.

${ }^{16}$ P. J. Perry and K. Galletly, 'The Preservation of Historic Buildings in Urban New Zealand: Precedent, Practice and Policy', New Zealand Geographer, vol 40 no 2, 1984, pp100-4.

${ }^{17} \mathrm{~J}$. E. Tunbridge and G. J. Ashworth, Dissonant Heritage: the management of the past as a resource in conflict, Wiley, Chichester, 1996.

${ }^{18}$ Laurajane Smith, Uses of Heritage, Routledge, London, 2006.

${ }^{19}$ There appears to be very little knowledge of the buildings profiled in this study. A list of buildings included in schedule 25.1 of the council's District Plan (1999), and formulated under the Resource Management Act, lists only a few of those buildings - but with nothing about their histories whatsoever. Often there is just a vague guess at the date of construction and an unreferenced assertion they were built by a particular well-known architect of the day. These 'scheduled' buildings (from a list compiled by Mark Garden dated 12.4.2002) lists a former Evening Star building on the corner of Bond and Police Streets, until recently occupied by Forno's Auctioneers. The record says only that 'this is a colourful well-modelled building with interesting window shapes.' The Otago A\&P Society's Brydone Hall is also scheduled, as 'previously used for annual A\&P winter shows.' Cromwell Chambers (Donald Reid's first warehouse) is recorded as making 'a significant contribution to the visual enclosure of Queens Gardens and also the townscape qualities in Dowling Street' (as the building has two street frontages). The Dunedin City Council has recently been handed a commissioned draft of a socalled Thematic Contextual Overview History for Dunedin City. The draft report, which is still to be considered by the council, was prepared by Michael Findlay and Salmond Reed Architects. There are also some important buildings and structures omitted from the study. Some, such as Farra Bros Engineering located in the existing or newer waterfront area, is one of these old established firms still operating. Others have been omitted on the basis that they are relatively high-profile and seemingly well looked-after buildings, which would also be listed under Historic Places Trust protection mechanisms. With the exception of A \& T Burt's brass foundry building in lower Stuart Street (now housing R\&R Sport), the Crown Roller Mill building (now apartments) and the Speights Brewery buildings (still operative) would fall under this category of high profile. A \& T Burt's old showroom, however, also has a relatively high profile in that it is a well-maintained and functioning shop. These three buildings were omitted from this study as they are not in the reclaimed area. 


\footnotetext{
${ }^{20}$ A.H. McLintock, The Port of Otago, Whitcombe and Tombs, Dunedin, 1951, p114. ${ }^{21}$ ibid, pp228-9.

22 'The smallest group of commercial establishments were the warehouses. There were only 118 of these each employing up to 30 workers. May of the bonded and free stores and general warehouses were two or three stories in height and covered an acre or more... the warehouse was often only part of a retail shop or a factory. Here produce was sorted, packed and repacked both for export and for local sale. The warehouses dealt with most of the material passing through the port. Briscoe's, one of the larger, but by no means the largest warehouse, had seven travellers on the staff to serve the South Island, as well as the normal warehousing staff.' W. A. V. Clark, 'Dunedin in 1901: A Study in Historical Urban Geography', MA thesis, University of Canterbury, Christchurch,1961, p53; K.C. McDonald, City of Dunedin: A Century of Civic Enterprise, Dunedin City Corporation, Dunedin, 1965, p77.

${ }^{23}$ Clark, pp24-5.

${ }^{24}$ McLintock, pp367-8.

${ }_{25}^{25}$ Erik Olssen, A History of Otago, John McIndoe Limited, Dunedin, 1984, pp56, 58, 66, 69.

${ }^{26}$ Dunedin City Planning Department, Dunedin's Historical Background, Dunedin, 1972, pp12-13. (Copy held by the DCC planning department.) This material may have come from K. C. McDonald's history of the Dunedin City Corporation.
}

${ }^{27}$ Gavin McLean, Otago Harbour: Currents of Controversy, Otago Harbour Board, Dunedin, 1985, p38.

${ }_{28}$ McLean, pp38, 90; McDonald, pp53, 180.

${ }^{29}$ Trevor Williams, 'Blair, William Newsham, 1841-1991', in Ministry for Culture and Heritage, Dictionary of New Zealand Biography, 1993-2010, http:/ / www.dnzb.govt.nz.

${ }^{30} \mathrm{~W}$. N. Blair, The Industries of New Zealand (Publication of an address given to the Industrial Association of Canterbury, 24 February 1887 - call no: V.055, Hocken Library, Dunedin), 1887, p8; Thornton, $\mathrm{p} 1$.

${ }^{31}$ ibid, pp11, 22, 13.

${ }^{32}$ Thornton, $\mathrm{p} 1$.

${ }^{33}$ Jim McAloon, No Idle Rich: The Wealthy in Canterbury and Otago 1840-1914, Otago University Press, Dunedin, 2002, p62. Details of individuals with overlapping interests include Ross and Glendining, John Wright, Thomas Brydone, J.M. Ritchie, John Roberts, James Hazlett, Thomas Kempthorne, James Mills and P. C. Neill: pp63-4.

${ }^{34}$ ibid, p65.

${ }^{35}$ Simon Ville, Rural Entrepreneurs: a history of the stock and station agent industry in Australia and New Zealand, Cambridge University Press, Cambridge, 2000, p210.

${ }^{36}$ Gordon Parry, N.M.A.: The Story of the First 100 Years, Otago Daily Times and Witness Newspapers, Dunedin, 1964, pp11-12, 28; Jim McAloon, 'Ritchie, John Macfarlane, 1842-1912', Dictionary of New Zealand Biography; McAloon, No Idle Rich, p13.

${ }^{37}$ Parry, p31.

${ }^{38}$ Parry, p114.

${ }^{39}$ McAloon, No Idle Rich, pp68-9.

${ }^{40}$ The Cyclopedia Company of New Zealand Ltd., Cyclopedia of New Zealand, vol 4: Otago and Southland Provincial Districts, The Cyclopedia Company of New Zealand Ltd, Christchurch, 1905, p349.

${ }^{41}$ ibid.

${ }^{42}$ Ville, p44.

${ }^{43}$ ibid, p65.

${ }^{44}$ ibid.

${ }^{45}$ Parry, p40.

${ }^{46}$ ibid.

${ }^{47}$ ibid. All three buildings are pictured here.

${ }^{48}$ In 1883 , according to the City Council's website:

http://www.dunedin.govt.nz/services/dunedin-heritage/list-of-assisted-projects/nma-

building, which also says the building changed hands in 1921 rather than 1929.

${ }^{49}$ Hardwicke Knight and Niel Wales, Buildings of Dunedin: An Illustrated Architectural Guide to New Zealand's Victorian City, John McIndoe, Dunedin, 1988, p208.

${ }^{50}$ This statement does not seem to appear in the version (November 2009) published on the City Council's website: <http:/ / www.dunedin.govt.nz/ services/dunedin-heritage/ dunedincontextual-thematic-history>.

${ }^{51}$ The grant was to 'contribute towards restoration works during redevelopment, including such items as repairs to marble stairs, tiling, cast iron grilles, and re-instating heritage window apertures': http://www.dunedin.govt.nz/services/dunedin-heritage/list-of-assistedprojects/nma-building. 
Public History Review | Trapeznik

\footnotetext{
${ }^{52}$ Otago Daily Times, 10 September 1883, p4; the permanent (and extant) railway station was not completed until 20 years later.

${ }^{53}$ McLean, p90.

${ }^{54}$ Olssen, A History of Otago, p67.

${ }^{55}$ ibid.

${ }^{56}$ ibid, p68.

${ }^{57}$ Thomson, p345.

${ }^{58}$ McLean, p93.

${ }^{59}$ Cyclopedia, p364; for its having been designed by Basil Hooper, see Ralph Allen, Motif and Beauty: The New Zealand Arts and Crafts Architecture of Basil Hooper, Harptree Press, Dunedin, 2000.

${ }^{60}$ Nizhny Tagil Charter.
} 